\title{
Effects of Awareness of Negative Leadership on Job Satisfaction and Intention to Change Jobs for Estheticians of Skin Care Salons
}

\author{
Moon-Joo Kim \\ Department of Medical Beauty, Ansan University, Ansan, Gyeonggi-do, Korea
}

Corresponding author: Moon-Joo Kim, Department of Medical Beauty, Ansan University, 155 Ansandaehak-ro, Sangrokgu, Ansan, Gyeonggi-do 426701, Korea

Tel.: +82 314007041

Fax: +82 313637705

Email: mjkim@ansan.ac.kr

Received January 5, 2021

Revised January 25, 2021

Accepted January 28, 2021

Published March 30, 2021

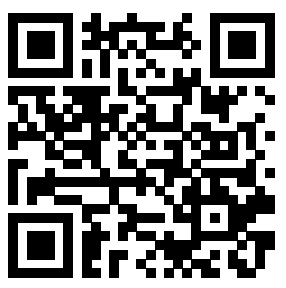

\begin{abstract}
Purpose: The study aimed to investigate the efficient operating mechanisms of the effect of negative leadership on job satisfaction and intention to change jobs among estheticians in the skin care salon industry. Methods: A literature review was performed and a questionnaire was designed to assess negative leadership, job satisfaction, and intention to change jobs. Random sampling was used to select participants in South Korea. Out of 560 questionnaires administered in June 2019, data from 472 respondents were included in the final analyses. The study conducted factor analyses and multiple regression analyses to examine relationships between variables and Cronbach's a for reliability analysis and validity analysis using SPSS window 19.0 (IBM, USA). Results: With regard to the correlation between negative leadership, job satisfaction, and intention to change jobs, estheticians reported that a self-regulating organization atmosphere, job satisfaction, desire for recognition, and relationship with peers were important. Conclusion: Improving working environments in skin care salons is necessary to create fair regulation, promotion, and welfare plans to decrease the effects of negative leadership on job satisfaction.
\end{abstract}

Keywords: Esthetician, Intention to change jobs, Job satisfaction, Negative leadership, Skin care salon

\section{Introduction}

\section{1. 연구의 필요성}

현대 사회의 다변화성은 불확실한 미래 경영 환경을 가져오게 하 고, 업체 간 경쟁 심화, 기술 속도의 가속화, 다양화 되어가는 고객의 요구는 서비스 업종인 피부미용실에서는 위기 요소가 될 수 있다. 그 러나 이러한 위기 상황을 기회요인으로 삼아 경영 환경을 변화시켜 간다면 차별화된 경쟁력을 확보 할 수 있으며 지속가능 경영을 이룰 수 있을 것이다(Kim \& Yoon, 2017).

피부미용실 운영에 있어서 다양한 요소가 존재 할 수 있으나, 가 장 핵심적인 요소는 인적 자원 관리가 될 것이다. 피부미용이라는 산 업의 특성상 주된 업무 영역이 고객 응대, 서비스 제공등과 같은 무 형의 생산과 소비를 이루어 내는 산업이므로, 그 주체인 피부미용사 에게 적절한 동기 부여를 통한 직무 만족도를 높이고, 이직의도를 줄 일 수 있다면 이는 피부미용실의 성과로 이어질 수 있을 것이다(Mo $\& \mathrm{Kim}, 2015)$. 이러한 맥락에서 볼 때 피부미용사의 직무 수행과정
에서 고객 서비스와 관련한 긍정적 태도와 행동, 실천 동기를 부여할 수 있는 관리자의 리더십은 매우 중요한 요소가 될 수 있다(Park \& Park, 2017). 기존의 리더십 관련 연구 동향을 살펴보면 하위 직원 들에게 긍정적 동기 부여를 통해 조직의 발전에 부응하는 행동을 일 으키는 긍정적인 리더십에 주된 초점을 두고 있었으나, 최근 부정적 리더십 연구를 통해 하위 직원들에게 미치는 좋지 않은 다양한 영향 요인을 밝히는 연구도 상당수 진행되고 있다(Lym \& Lee, 2013). 이 와 같은 연구 동향은 초기연구에서 심리학의 주요 이슈로 다루어져 왔으나, 최근에는 경영학, 사회학, 소비자학 등 다양한 분야에서 연 구가 진행되고 있다(Joo, 2014). 관리자의 리더십은 하위 직원들에 게 직접적인 영향을 미칠 수 있으며 이는 피부미용실 존립과도 상당 부분 연관성이 있다. 따라서 본 연구는 관리자의 부정적 리더십 지각 이 피부미용사의 직무 만족도와 이직 의도 간의 관계를 알아보는 것 은 피부미용사의 직무만족도를 향상시키고 이직의도를 감소시킴으 로써 피부미용 경영환경의 안정화 및 발전을 위한 기초 자료 제공에 기여할 것으로 기대된다. 


\section{2. 연구의 목적 및 의의}

부정적 리더십이란 상사가 자신의 권력을 남용하여 타인과 전체 조직에 대해 부정적이고 파괴적인 영향력을 행사하는 것으로 자신의 지속적 성장에 장애가 되는 행동을 스스로 보일 뿐만 아니라 언어적, 비언어적 적대 행동을 지속적으로 부하 직원들에게 보임으로써 조직 의 핵심가치, 행동기준, 공유 규범과 기대를 위반하는 행동을 나타내 며, 이는 비윤리적이며 비효과적인 조직 행동으로 이어진다 할 수 있 다(Jeon \& Moon, 2014). 현대에서의 조직의 의미는 해당 조직에 소 속된 구성원들이 조직에 만족, 몰입하는 정도에 따라 해당 조직의 성 과와 발전이 결정된다(Lym \& Choi, 2016). 조직 구성원들의 지각하 고 있는 조직 내 근무 여건에 따라 만족도는 조직의 목표 달성, 경영 성과, 구성원간의 인간관계를 통한 조직 내 분위기에 중요한 영향 요 인으로 작용한다(Shin et al., 2017). 조직 구성원들이 조직 내 분위 기, 상사의 리더십, 인간관계에 만족할수록, 일에 대한 보람을 느끼 고, 스스로 공헌하고자 하는 의지가 높아지며 이는 경영 성과로 이어 지게 된다(Hwang \& Yoo, 2013). 반대로, 조직 구성원들이 근무 여 건, 환경, 분위기에 불만족하게 느낀다면 조직에 대한 애착심을 잃 게 되고 이는 근무의욕 및 직무 성과에 영향을 미치게 된다. 또한 지 속적으로 악화된 조직 분위기는 조직 구성원들로 하여금 조직 및 상 사에 대한 저항심을 야기 시키며, 이직 의도를 높이게 된다(Bae \& Park, 2015).

이직의도란 조직 내 구성원들이 조직을 떠나고자 하는 의향으로 특히 고객 환대 및 서비스를 중심으로 한 서비스 기업에 있어서 직 원들의 이직의도 상승은 경영 성과와 밀접한 연관성이 있다(Gang \& Lee, 2019). 직원들의 이직의도 상승은 고객 이탈을 조장하고, 장기 적인 고객 유치를 위한 고객, 직원간의 관계를 악화시키며, 고객과의 친밀한 관계 형성 및 대고객 서비스에도 악영향을 미치게 된다(Lee et al, , 2013). 이에 본 연구에서는 피부미용사를 대상으로 부정적 리 더십 지각이 직무만족도와 이직의도에 미치는 영향에 대해 알아보고 이를 통해 피부미용실 운영 기업에서의 개선 방안을 마련함으로써 기업, 피부미용사 및 고객 모두에게 도움이 될 수 있는 효율적인 경 영 관리 방안 마련을 위한 기초 자료 제공에 본 연구의 의의가 있다.

\section{Methods}

\section{1. 연구 대상 선정 및 자료 수집 기간}

본 연구를 수행하기 위한 연구 대상자는 전국 프랜차이즈 피부미 용실 87 곳, 개인운영 피부미용실 25 곳에 근무하는 피부미용사로 설 정하였다. 자료 수집 방법은 피부미용실 원장 또는 실장을 통해 연구 취지를 설명들은 피부미용사들이 구조화된 설문지를 이용하여 직접 자기기입식으로 작성하였으며, 조사 기간은 2019년 6월 3일부터 6 월 28 일까지 실시하였으며, 총 112 개의 피부미용실에 560 부의 설문 지를 배포하여 회수된 472 부가 분석에 사용되었다.

\section{2. 조사도구}

1) 일반적 특성

본 연구에서는 응답자의 일반적 특성으로 성별, 연령, 학력, 직 급, 근무기간, 평균 월 소득으로 총 6 개 문항으로 구성하였고, 측정 방법은 명목척도를 사용하였다.

\section{2) 부정적 리더십 요인}

부정적 리더십이란 상사 또는 리더가 조직과 조직 구성원들의 목 표 달성을 방해하는 직. 간접적 역기능 행동을 보이는 것으로 정의 할 수 있다(Lee \& Jeong, 2012). Joo (2014)는 리더가 조직의 목적, 사명, 자원, 효율성, 부하 직원의 동기부여, 만족도 등을 훼손하거나 저해하는 행위를 반복적이면서도 체계적으로 하는 것이라 하였다. Jeon \& Moon (2014), Hwang \& Yoo (2013)의 연구를 참조하여 연 구자가 연구 목적에 맞도록 일부 수정하여 근무 환경 요인 7문항, 개 인적 요인 5 문항으로 총 12 문항을 선정하였다.

\section{3) 직무 만족도 요인}

직무만족도란 조직 내에서 조직 구성원들이 지각하고 있는 근 무 환경, 구성원 간 인간관계에 대한 주관적 만족 수준으로 정의 할 수 있다(Kim \& Kim, 2016). Seong et al. (2017)는 조직 구성원들 이 근무 환경에 만족하는 것은 자신과 조직을 위해 공헌하는 것에 보 람을 느끼고, 이를 통해 조직성과가 높아진다고 하였다. Seo \& Kim (2016), Kim (2015), Lee (2015)의 연구를 참조하여 연구자가 연구 목적에 맞도록 일부 수정하여 기회요인 8 문항, 능력요인 4 문항, 방 향요인 4 문항으로 총 16 개 문항을 선정하였다.

4) 이직의도 요인

이직의도란 자신이 속한 조직과 자신의 수행하던 직무를 떠나고 자 하는 의향을 뜻하는 것으로 이직 행동의 중요한 영향원으로 작용

\section{Table 1. Composition of questionnaire}

\begin{tabular}{llc}
\hline Variable (general characteristics) & Measurement & Frequency \\
Negative leadership factors & Five-point Likert-type measure & 12 \\
Job satisfaction factors & Five-point Likert-type measure & 16 \\
Intend of change job factors & Five-point Likert-type measure & 4 \\
Total & & 38 \\
\hline
\end{tabular}


한다(Jeong \& Lee, 2014). Yang et al., (2014)는 계획된 행동 이론 에서의 태도, 주관적 규범, 지각된 행동 통제감과 관련한 상호 영향 을 나타내며, 이직의도를 통한 태도변화는 직적적인 이직 행동에 영 향을 미친다고 하였다. Jeong \& Lee (2014), Yang et al. (2014)의 연구를 참조하여 연구자가 연구 목적에 맞도록 일부 수정하여 총 4 개 문항을 선정하였다.

\section{3. 분석방법}

본 연구의 자료는 SPSS window 19.0 프로그램(IBM, USA)을 사 용하여 다음과 같은 방법으로 분석하였다. 연구 대상자의 일반적 특 성은 명목척도를 사용하였고, 부정적 리더십 지각 요인, 직무 만족 도 요인, 이직의도 요인 문항은 리커트 5점 척도를 사용하였다. 설문 지의 구성은 Table 1 과 같다. 구체적으로 유효표본의 일반적 특성을 파악하기 위하여 빈도분석, 각 설문항목의 신뢰성과 타당성 검증은
Cronbach's $\alpha=$ 와 요인분석, 부정적 리더십 지각 요인이 직무 만족도 요인과 이직의도에 미치는 인과관계를 검증하기 위하여 요인 값을 이용한 다중회귀분석을 이용하였다.

\section{Results}

\section{1. 연구 대상자의 일반적 특성}

연구대상자의 일반적 특성은 Table 2 와 같다. 성별에서 여성은 449 명 $(95.1 \%)$ 로 나타났다. 연령의 경우 20 세 이상 30 세 미만이 가 장 많아 201명(42.6\%)을 나타내었고, 다음으로 30세 이상 40세 미 만이 120 명(25.4\%)를 나타내었다. 학력의 경우 전문대학 졸업이 가 장 많아 275명(58.3\%)로 가장 많았고, 다음으로 대학교 졸업이 113 명(123.9\%) 순으로 나타났다. 직급의 경우 피부미용사가 가장 많아

\section{Table 2. General characteristics}

\begin{tabular}{|c|c|c|}
\hline Provision & Variables & Frequency (\%) \\
\hline \multirow{2}{*}{ Gender } & Male & $23(4.9)$ \\
\hline & Female & $449(95.1)$ \\
\hline \multirow{5}{*}{ Age (years) } & Less than 20 years & $31(6.6)$ \\
\hline & $21-30$ & $201(42.6)$ \\
\hline & $31-40$ & $120(25.4)$ \\
\hline & $41-50$ & 75 (15.9) \\
\hline & More than 50 & $45(9.5)$ \\
\hline \multirow{4}{*}{ Academic achievement } & High school or less & $49(10.4)$ \\
\hline & College & $275(58.3)$ \\
\hline & University & $113(23.9)$ \\
\hline & Graduate school & $35(7.4)$ \\
\hline \multirow{6}{*}{ Position } & Esthetician & $180(38.1)$ \\
\hline & Manager & 97 (20.6) \\
\hline & Vice-president & $62(13.1)$ \\
\hline & Part-time job & $18(3.8)$ \\
\hline & Trainee & $107(22.7)$ \\
\hline & Others & $8(1.7)$ \\
\hline \multirow{5}{*}{ Work tenure } & Less than 1 year & $203(43.0)$ \\
\hline & $>1$ year to $<2$ years & $103(21.8)$ \\
\hline & $>2$ years to $<3$ years & $60(12.7)$ \\
\hline & $>3$ years to $<4$ years & $57(12.1)$ \\
\hline & $>4$ years & $49(10.4)$ \\
\hline \multirow{6}{*}{ Monthly income (Unit: 1,000 won) } & Less than 1,000 & $75(15.9)$ \\
\hline & $>1,000$ to $<2,000$ & $93(19.7)$ \\
\hline & $>2,000$ to $<3,000$ & $120(25.4)$ \\
\hline & $>3,000$ to $<4,000$ & $72(15.3)$ \\
\hline & $>4,000$ to $<5,000$ & $67(14.2)$ \\
\hline & More than 5,000 & $45(9.5)$ \\
\hline
\end{tabular}


180명(38.1\%) 이었고 다음으로 수습생으로 107명(22.7\%)로 나타 났다. 근무 기간의 경우 1 년 이하가 가장 많아 203명(43.0\%)를 나 타내었고, 다음으로 1 년 이상 2 년 이하가 103 명(21.8\%)로 나타났 다. 월 급여의 경우 200 만원 이상 300 만원 이상이 가장 많아 120 명 (25.4\%)을 나타내었고, 다음으로 100 만원 이상 200만원 미만이 93 명(19.7\%)로 나타났다.

\section{2. 측정 도구의 신뢰성 및 타당성 분석}

1) 부정적 리더십 요인의 신뢰성 및 타당성 분석

부정적 리더십 요인에 영향을 미치는 요인의 차원을 도출하기 위
해 베리맥스 회전법을 통한 주성분 분석을 실시하였으며 신뢰성 분 석을 위해 각 요인별로 신뢰도 계수(Cronbach's $\alpha=)$ 를 계산하였다 (Table 3).

부정적 리더십 요인의 신뢰성 및 타당성 분석결과 근무 환경 요인 (Cronbach's $\alpha=0.795)$, 개인적 요인(Cronbach's $\alpha=0.801)$ 로 신뢰할 만한 수준에 있다고 볼 수 있다.

2) 직무 만족도 요인의 신뢰성 및 타당성 분석

직무 만족도를 나타내는 차원을 도출하기 위해 베리맥스 회전법 을 통한 주성분 분석을 실시하였으며 신뢰성 분석을 위해 각 요인별

Table 3. Results of reliability and validity analyses on negative leadership factors

\begin{tabular}{lccc}
\hline Variables & Eigen value & Degree of dispersion & Cronbach's $\alpha$ \\
Service environmental factor & 4.694 & 31.204 & 0.795 \\
Personal factor & 5.007 & 27.669 & 0.801 \\
\hline
\end{tabular}

Keiser-Meyer-Olkin=0.782; Bartlett's gutter certification value $x^{2}=1356.220$; total $=72.361 \%$.

Table 4. Results of reliability and validity analyses on job satisfaction factors

\begin{tabular}{lcc}
\hline Variables & Eigen value & Degree of dispersion \\
Opportunity factor & 3.947 & 27.556 \\
Ability factor & 4.009 & 24.597 \\
Direction factor & 4.694 & 22.307 \\
\hline
\end{tabular}

Keiser-Meyer-Olkin=0.857; Bartlett's gutter certification value $x^{2}=1289.601$; total $=84.237 \%$.

Table 5. Results of reliability and validity analyses on intention to change jobs

\begin{tabular}{lcc}
\hline Variable & Eigen value & Degree of dispersion \\
Intention to change jobs & 4.200 & 29.647 \\
\hline Keiser-Meyer-Olkin=0.755; Bartlett's gutter certification value $x^{2}=1297.266$; total=66.201\%.
\end{tabular}

Table 6. Results of factor analysis on negative leadership

\begin{tabular}{|c|c|c|c|c|c|}
\hline Factor & Variables & Mean & Standard deviation & Ranking in factor & Ranking in total \\
\hline \multirow{7}{*}{$\begin{array}{l}\text { Work-related } \\
\text { factor }\end{array}$} & The supervisor does not follow rules. & 4.071 & 0.842 & 4 & 7 \\
\hline & $\begin{array}{l}\text { The supervisor treats employees } \\
\text { different from the management staff. }\end{array}$ & 4.140 & 0.912 & 2 & 4 \\
\hline & $\begin{array}{l}\text { The supervisor promotes } \\
\text { heteronomous organizational } \\
\text { circumstances. }\end{array}$ & 4.275 & 0.951 & 1 & 2 \\
\hline & $\begin{array}{l}\text { The supervisor does not change } \\
\text { circumstances. }\end{array}$ & 3.758 & 0.826 & 5 & 9 \\
\hline & $\begin{array}{l}\text { The supervisor lacks clearly set } \\
\text { goals. }\end{array}$ & 3.214 & 1.093 & 6 & 11 \\
\hline & $\begin{array}{l}\text { The supervisor generates distrust } \\
\text { from employees. }\end{array}$ & 3.174 & 0.762 & 7 & 12 \\
\hline & $\begin{array}{l}\text { The supervisor does not promote } \\
\text { new leaders. }\end{array}$ & 4.107 & 0.763 & 3 & 5 \\
\hline \multirow{5}{*}{ Personal factor } & The supervisor is inhumane. & 4.102 & 0.691 & 3 & 5 \\
\hline & $\begin{array}{l}\text { The supervisor does not promote } \\
\text { shared values. }\end{array}$ & 4.371 & 0.659 & 1 & 1 \\
\hline & $\begin{array}{l}\text { The supervisor lacks professional } \\
\text { knowledge. }\end{array}$ & 3.941 & 0.819 & 4 & 8 \\
\hline & The supervisor is lazy. & 3.250 & 1.003 & 5 & 10 \\
\hline & $\begin{array}{l}\text { The supervisor does not trust } \\
\text { employees. }\end{array}$ & 4.152 & 1.308 & 2 & 3 \\
\hline
\end{tabular}


로 신뢰도 계수(Cronbach's $\alpha$ )를 계산하였다(Table 4).

직무 만족도 요인의 신뢰성 및 타당성 분석결과 기회 요인 (Cronbach's $\alpha=0.824)$, 능력 요인(Cronbach's $\alpha=0.799)$, 방향 요인 (Cronbach's $\alpha=0.764)$ 로 신뢰할 만한 수준에 있다고 볼 수 있다.

\section{3) 이직 의도 요인의 신뢰성 및 타당성 분석}

이직의도를 나타내는 차원을 도출하기 위해 베리맥스 회전법을 통한 주성분 분석을 실시하였으며 신뢰성 분석을 위해 각 요인별로 신뢰도 계수(Cronbach's $\alpha$ )를 계산하였다(Table 5).

이직 의도 요인의 신뢰성 및 타당성 분석결과 Cronbach's $\alpha=0.812$ 로 신뢰할 만한 수준에 있다고 볼 수 있다.

\section{3. 부정적 리더십 및 직무 만족도 요인 분석}

1) 부정적 리더십 요인 분석

부정적 리더십 요인 분석 결과는 Table 6과 같다. 근무 환경 요인 에서 '타율적인 조직 분위기'(4.275 \pm 0.951$)$, '공정한 대우를 하지 않

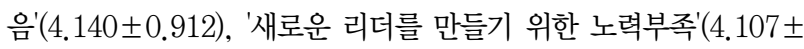
0.763)의 순으로 나타나, 피부미용사들은 관리자의 지시에 의해 자 율적인 분위기로 자신의 역량 발휘를 하는데 제한을 두는 점, 관리사
들 간의 공정한 대우를 받지 못할 때, 미래를 위한 기술 습득 시 관리 자가 소극적일 때 부정적 리더십으로 간주하는 것으로 나타났다. 개

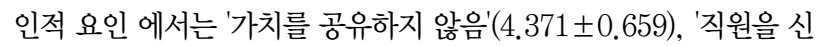

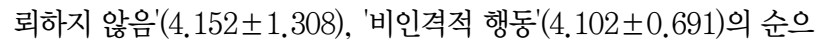
로 나타나, 피부 관리실 운영을 통해 얻어진 이윤에서의 부당한 배 분, 피부미용사가 관리자로부터 신임 받지 못할 때, 관리자의 비인격 적 행동으로 인한 상처를 받았을 때 부정적 리더십으로 인지하고 있 었다.

\section{2) 직무 만족도 요인 분석}

직무 만족도 요인 분석 결과는 Table 7과 같다. 직무 만족도의 요 인을 분석하기 위해 기회 요인, 능력 요인, 방향 요인으로 구분하여 분석하였다. 먼저, 기회 요인에서 독립적(4.310 0.861$)$, 사회적 봉

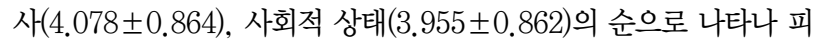
부미용사들은 자신이 사회에서 어떤 일을 독립적으로 서비스함으로 써 자신의 역량을 발휘할 수 있는 것에 대한 직무 만족도를 가지고

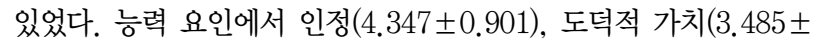
0.800)의 순으로 나타나, 자신 또는 고객으로부터 받는 인정, 자신 의 의지에 따른 행동을 함으로써 직무 만족도가 높아지는 것으로 나

Table 7. Results of factor analysis on job satisfaction factors

\begin{tabular}{|c|c|c|c|c|c|}
\hline Factor & Variables & Mean & Standard deviation & Ranking in factor & Ranking in total \\
\hline \multirow{8}{*}{ Chance } & Independence & 4.310 & 0.861 & 1 & 3 \\
\hline & Variety & 3.712 & 0.863 & 4 & 8 \\
\hline & Social status & 3.955 & 0.862 & 3 & 7 \\
\hline & Social service & 4.078 & 0.864 & 2 & 5 \\
\hline & Authority & 3.359 & 0.793 & 6 & 12 \\
\hline & Creativity & 3.214 & 1.034 & 7 & 13 \\
\hline & Advancement & 3.175 & 1.620 & 8 & 14 \\
\hline & Ability utilization & 3.375 & 0.731 & 5 & 11 \\
\hline \multirow{4}{*}{ Ability } & Activity & 2.847 & 0.763 & 4 & 16 \\
\hline & Technical supervision & 3.174 & 0.746 & 3 & 14 \\
\hline & Moral values & 3.485 & 0.800 & 2 & 9 \\
\hline & Recognition & 4.347 & 0.901 & 1 & 2 \\
\hline \multirow{4}{*}{ Direction } & Security & 3.392 & 0.920 & 4 & 10 \\
\hline & Skin care salon prices & 4.048 & 0.904 & 3 & 6 \\
\hline & Supervision human relations & 4.261 & 0.762 & 2 & 4 \\
\hline & Co-workers & 4.402 & 0.763 & 1 & 1 \\
\hline \multicolumn{2}{|l|}{ Variables } & Mean & Standard deviation & Ranking in factor & Ranking in total \\
\hline \multicolumn{2}{|c|}{ I intend to find jobs unrelated to skin care. } & 3.250 & 0.903 & 4 & 4 \\
\hline \multicolumn{2}{|c|}{ I intend to find jobs with other skin care salons. } & 4.081 & 0.861 & 3 & 3 \\
\hline \multicolumn{2}{|c|}{ I gathered information on other skin care salons. } & 4.322 & 0.763 & 2 & 2 \\
\hline \multicolumn{2}{|c|}{ I frequently hope to quit working in this salon. } & 4.549 & 0.800 & 1 & 1 \\
\hline
\end{tabular}




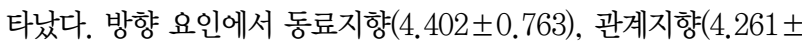
0.762)의 순으로 직무만족도가 높아지는 것으로 나타났다.

\section{3) 이직의도 요인 분석}

이직의도 요인 분석 결과는 Table 8 과 같다. '나는 가끔 지금의 피부미용실을 그만두기를 원한다'(4.549 \pm 0.800$)$ 으로 이직의도가 매우 높게 나타났고, '나는 다른 피부미용실의 정보를 얻기 위해 노 력한다'(4.32 \pm 0.763$)$, '나는 다른 피부미용실로 이직하기를 원한

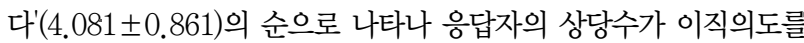
가지고 있는 것으로 조사되었다. 그러나 '나는 피부관리 분야가 아닌 직업으로 이직하기를 원한다'(3.250 \pm 0.903$)$ 으로 나타나 타 업종으 로의 이직의도는 낮게 나타났다.

\section{4. 부정적 리더십과 직무 만족도 및 이직 의도와의 상관관계}

부정적 리더십과 직무 만족도와 상관관계를 본 연구 결과는 Table 9 와 같다. 부정적 리더십 하위 변수로써의 근무 환경 요인 에서 부정적 리더십이 높을수록 직무 만족도가 낮았으며(Pearson correlation $\mathrm{r}=-0.281, p<0.001)$, 개인적 요인에서 부정적 리더십 이 높을수록 직무 만족도가 낮게 나타났다(Pearson correlation $\mathrm{r}=-$ $0.194, p<0.001)$. 이는 장애인 야학교사의 직무만족도를 분석한 선 행연구(Kim \& Kim, 2016)에서 직업에서의 직무 만족도란 개인이 자신의 능력과 적성에 맞는 직업을 선택하여 만족감을 느끼고 생활 하는 것은 자아실현과 성장을 가능하게 하는 중요한 요인이며 이는 작업 환경에서의 주관적 만족도가 높을수록 직무만족이 높게 나타난 다고 주장하여 본 연구 결과를 지지하고 있다. 경찰 공무원의 직무 스트레스 요인별 직무 만족도에 관한 선행연구(Kim, 2015)에서 경 찰 공무원들은 직업을 통해 인간관계, 성취감, 생활의 안정, 사회경 제적 지위 등에 영향을 받기 때문에 직무만족은 직업 활동 자체에 국 한되는 것이 아니라 개인의 삶의 질과 방향까지 결정하는 중요한 요 소로써 작용 한다고 하였고, 이를 위해 직업 환경에서의 안정적인 긍 정적인 인간관계, 성취감, 사회적으로 인정된 지위의 확보는 직무만 족에 정(+)의 영향을 미친다고 주장하여 본 연구 결과를 지지하고 있 다.
부정적 리더십과 이직의도와의 상관관계를 본 연구 결과는 Table 10 과 같다. 부정적 리더십 하위 변수로써의 근무 환경 요인에서 부 정적 리더십이 높을수록 이직의도 높았으며(Pearson correlation $\mathrm{r}=0.299, p\langle 0.01)$, 개인적 요인에서 부정적 리더십이 높을수록 이 직의도가 높게 나타났다(Pearson correlation $\mathrm{r}=0.301, p\langle 0.01$ ). 이 는 남성 헤어 디자이너의 이직의도가 직업 전환에 미치는 영향에 관 하여 연구한 선행연구(Bae \& Park, 2015)에서 직무성과와 이직과 의 정적 부호관계는 공정성(equity) 가설과도 연결이 된다고 주장하 였는데 즉, 성과가 높음에도 불구하고 그에 상응하는 보상을 받지 못 한 조직원의 경우, 불공정성을 지각할 가능성이 높아지고, 이러한 불 공정성은 조직이동이 용이할 경우 이직으로 표출된다고하여 본 연구 결과를 지지하고 있다.

\section{Discussion}

피부미용실 운영에 가장 핵심적인 요소는 인적 자원 관리라 할 수 있다. 그러나 타 업종에 비해 피부미용실의 인적자원관리는 이직률 이 높은 서비스 업종의 특성상 안정적인 경영관리에 어려움이 많은 것이 현실이다. 그러므로 차별화된 경쟁력을 확보하고 지속가능한 경영을 이루기 위해서는 안정적인 인적 자원 관리가 매우 중요한 요 소라 할 것이다. 이러한 맥락에서 볼 때 피부미용사의 직무 수행과정 에서 고객 서비스와 관련한 긍정적 태도와 행동, 실천 동기를 부여할 수 있는 관리자의 리더십은 매우 중요한 요소가 될 수 있다. 기존의 연구들 대부분이 조직 구성원에게 긍정적 동기 부여를 하고, 이를 통 한 생산성 확립을 강조하였으나, 최근 연구 동향들은 이와 반대로 부 정적 리더십의 요소를 파악하고 이를 개선해 나가는 방향으로 진행 되는 경향이 높다. 다양한 분야에서 이와 같은 연구들이 진행되고 있 으나, 아직까지 피부미용관련 부정적 리더십 연구가 미흡한 상황이 다. 피부미용실의 관리자의 리더십은 피부미용사들에게 직접적인 영 향을 미칠 수 있으며 이는 피부미용실 존립과도 상당부분 연관성이 있다. 따라서 본 연구는 관리자의 부정적 리더십 지각이 피부미용사 의 직무 만족도와 이직 의도 간의 관계를 살펴봄으로써 향후 피부미

Table 9. Correlation between negative leadership and job satisfaction

\begin{tabular}{lcc}
\hline Variables & Negative leadership & Job satisfaction \\
Work-related factors & 0.849 & $-0.281^{* * *}$ \\
Personal factors & 0.716 & $-0.194^{* * *}$ \\
${ }^{* * *} p<0.001$. & &
\end{tabular}

Table 10. Correlation between negative leadership and intention to change jobs

\begin{tabular}{lcc}
\hline Variables & Negative leadership & Job satisfaction \\
Work-related factors & 0.751 & $0.299^{* *}$ \\
Personal factors & 0.708 & $0.301^{* *}$ \\
\hline$* *$
\end{tabular}

${ }^{* *} p<0.01$. 
용실 경영과 직원 관리 등의 기초 자료로 활용하고자 진행하였다. 본 연구의 연구결과 및 제언은 다음과 같다.

첫째, 부정적 리더십 요인 분석 결과 근무 환경 요인에서 '타율적 인 조직 분위기', '공정한 대우를 하지 않음', '새로운 리더를 만들기 위한 노력부족'의 순으로 나타나, 피부미용사들은 관리자의 지시에 의한 타율적 분위기를 가장 불편하게 생각하고 있었다. 이는 최근 사 회 전반적으로 자율을 강조하고, 이에 익숙한 피부미용사들에게 타 율적 조직 분위기는 중압감으로 작용하고 이에 대한 부정적 느낌을 가지게 되는 것으로 사료된다. 또한, 규정에 의거한 공정한 대우를 받기를 원하고 있었으며, 향후 미래의 관리자로 발전하기 위한 준비 과정에서 현재의 관리자의 도움을 받기를 원하고 있었다. 이와 같은 점들에 기인하여 관리자들은 현재의 부정적으로 인식되는 리더십 개 선이 요구된다. 이와 관련하여 학교장의 부정적 리더십 연구에 관한 탐색적 고찰을 한 선행연구(Joo, 2014)에서 부정적 리더십은 조직의 목표 달성에 필요한 핵심적인 요소를 갖추지 못하고 있어 조직의 긍 정적인 변화를 어렵게 만든다고 주장하여 본 연구 결과를 지지하고 있다.

개인적요인에서는 '가치를 공유하지 않음', '직원을 신뢰하지 않 음', '비인격적 행동'의 순으로 나타났다. 피부미용사들이 인식하고 있는 가장 중요한 가치란 경제적 가치를 생각하고 있었으며, 이러한 가치 공유가 납득할 만한 수준에서 이행되지 못할 때 부정적 견해를 가지고 있었다. 최근 최저시급 인상과 관련한 사회적 분위기를 고려 하여 임금의 적정선 유지를 이루는 것이 시급하다. 또한 피부미용사 를 신뢰하지 않는 관리자의 태도는 또 다른 불신을 낳게 됨으로 서로 신뢰하는 직장 분위기 마련이 중요할 것이다. 비인격적 행동과 관련 하여 직원의 인성개발뿐만 아니라 관리자의 지속적인 인성 개발, 자 기계발 관련 노력을 게을리 해서는 안 됨을 시사하고 있다. 이와 관 련하여 부정적인 측면의 카리스마적 리더십에 대하여 연구한 선행연 구(Jeon \& Moon, 2014)에서는 부정적 리더십, 구성원의 반응, 조직 내외의 환경 등 관련 변인 간의 관계를 분석하였는데 부정적 리더십 은 리더십을 발휘하는 과정 중에 드러난 리더의 성격, 태도, 행동, 능 력이 중요한 요인으로 분석되었다. 부정적 리더십을 폭군, 허구의 거 래적 리더십, 사유화된 카리스마, 무능한 리더십, 독성의 리더십, 파 괴적 리더십, 난폭한 감독, 전략적 괴롭힘으로 구분하였으며, 이는 구성원들 간의 불신과 직장 내 긍정적인 분위기를 파괴하는 요인이 된다고 주장하여 본 연구 결과를 지지하고 있다.

둘째, 직무 만족도의 요인을 분석하기 위해 기회 요인, 능력 요인, 방향 요인으로 구분하여 분석하였다. 먼저, 기회 요인에서 '독립적 으로 일할 기회(independence)', '다른 사람들을 위해 어떤 일을 할 수 있는 기회(social service)', '사회에서 역량을 발휘할 수 있는 기회 (social status)'의 순으로 나타나 피부미용사들은 단지 급여를 위한 직업이 아닌 자신이 사회에서 어떤 일을 독립적으로 서비스함으로써 자신의 역량을 발휘할 수 있는 것에 대한 직무 만족도를 가지고 있음 을 알 수 있었다. 능력 요인에서 '자신의 일을 함으로써 얻게 되는 인 정(recognition)', '나의 의지에 반하지 않는 행동(moral value)'의 순 으로 나타났다. 자신 스스로 인정할 수 있는 인정 욕구 및 이를 직업 에서 표현할 수 있는 행동의 중요성을 인지하고 있었다. 방향 요인 에서 '동료와 좋은 관계를 유지하는 방향(co-workers)', '관리자가 피부미용사들과 좋은 관계를 유지하기 위한 방향(relations)'의 순으 로 직무만족도가 높아지는 것으로 나타났다. 작은 규모의 직장 내에 서 동료와 좋은 관계를 유지하고, 또한 관리자가 좋은 직장 내 분위 기를 만들기 위해 노력하는 것들이 직무 만족도를 향상 시킬 수 있는 좋은 방법임을 알 수 있었다. 이와 관련하여 중등 교사의 학교장 지 도성, 교사변인, 조직 변인과 직무만족도에 관한 메타분석을 연구한 선행연구(Hwang \& Yoo, 2013)에서 직무 만족이란 단지 직무 하나 만을 의미하는 것이 아니 직무 수행에 따른 인간관계, 직무와 관련된 개인의 감정적 태도, 근로조건 등 여러 다른 요소를 포함한 직무에 대한 정서적 반응이라 주장하여 본 연구 결과를 지지하고 있다. 서울 시 특 1 급 호텔 종사자를 대상으로 직무자율성, 직무만족, 정서적 조 직 몰입과 지식공유 행동의 구조적 영향관계를 연구한 선행연구(Lee et al., 2013)에서 종사자들은 자신의 재능과 능력에 따라 직업에 종 사하기를 희망하며, 직업 성취, 임금, 직업, 직무 만족이 이에 중요한 요소가 된다고 주장하여 본 연구 결과를 지지하고 있다.

셋째, 이직의도 요인 분석 결과 '나는 가끔 지금의 피부미용실을 그만두기를 원한다'로 이직의도가 매우 높게 나타났고, '나는 다른 피 부미용실의 정보를 얻기 위해 노력한다', '나는 다른 피부미용실로 이 직하기를 원한다'의 순으로 나타나 응답자의 상당수가 이직의도를 가지고 있는 것으로 조사되었다.

넷째, 부정적 리더십과 직무 만족도와 상관관계를 본 결과 근무 환경 요인에서 근무 환경 요인에서 부정적 리더십이 높을수록 직무 만족도가 낮았으며, 개인적 요인에서 부정적 리더십이 높을수록 직 무 만족도가 낮게 나타났다. 즉, 부정적 리더십은 직무 만족도와 부 $(-)$ 의 관계를 형성함으로써 관리자의 부정적 리더십 개선이 피부미 용사들의 직무 만족도 향상과 밀접한 관계가 있음을 시사한다. 부정 적 리더십과 이직의도와의 상관관계를 본 연구 결과 근무 환경 요인 에서 부정적 리더십이 높을수록 이직의도 높았으며, 개인적 요인에 서 부정적 리더십이 높을수록 이직의도가 높게 나타났다. 즉, 피부미 용사들의 이직을 줄이고 직장 내 좋은 분위기 마련을 통한 직무 만족 도를 높이기 위해서는 관리자의 부정적 리더십 개선 노력이 매우 중 요함을 알 수 있다. 이와 관련하여 상사 신뢰의 매개효과와 회복탄력 성의 조절 효과를 중심으로 상사의 비인격적 감독 행동이 조직 효과 성에 미치는 영향을 연구한 선행연구(Lym \& Lee, 2013)에서 상사 의 부정적, 폭력적 리더십은 구성원의 부정적 대응(아첨, 부정적 감 정), 직무부담(직무 긴장과 감정 소진) 및 이직의도에 정(+)의 영향력 을 미친다고 하여 본 연구 결과를 지지하고 있다. 정서적 몰입에 따 른 호텔 주방 부서장의 감독 유형 요인과 구성원의 직무 만족 간 영 향 관계를 연구한 선행연구(Shin et al., 2017)에서 파괴적 리더십과 직무 환경, 직무 성격 간에는 상호작용이 나타나며 구성원의 심리적, 
신체적 중압감과 직무 태도, 헌신에 부정적인 효과를 나타낸다고 하 여 본 연구 결과를 지지하고 있다.

\section{Conclusion}

본 연구는 다음과 같은 한계점을 갖는다. 첫째, 표본의 대표성 문 제이다. 본 연구를 위한 표본으로 전국에 위치한 프랜차이즈 피부미 용실, 개인 운영 피부미용실 일부로 한정하여 조사하였으며, 본 연구 결과를 일반화하기에는 다소 무리가 있다고 생각된다. 둘째, 부정적 리더십 요인으로 근무 환경 요인, 개인적 요인으로 총 12 개 문항, 직 무 만족도 요인으로 기회 요인, 능력 요인, 방향요인의 총 16 개 문항 을 살펴보았으며, 이직 의도 요인으로 총 4 개 문항을 살펴보았으나, 이를 통한 연구 결과는 한정적일 수밖에 없다. 그러나 그럼에도 불구 하고 본 연구 결과가 기준 선행 연구결과와 동일한 결과이면서 관리 자의 부정적 리더십을 낮추고 피부미용사의 직무 만족도를 증진시키 고 이직 의도를 낮출 수 있는 요인을 살펴봄으로써 추후 피부미용실 의 경영개선 및 관리자들의 부정적 리더십에 대한 관심 및 개선의지 를 높을 수 있는 방향으로의 발전을 위한 기초 자료로 활용이 가능할 것으로 사료된다.

\section{Author's contribution}

MJK designed, analyzed data, and wrote the manuscript.

\section{Author details}

Moon-Joo Kim (Professor), Department of Medical Beauty, Ansan University, 155 Ansandaehak-ro, Sangrokgu, Ansan, Gyeonggi-do 426701, Korea.

\section{References}

Bae EM, Park EJ. Research on the effects of a turnover intention of male hair designers on an occupational change. Asian Journal of Beauty and Cosmetology, 13: 595-602, 2015.

Gang CH, Lee JH. A study of social workers' turnover intention: analysis on organizational mobility and occupational mobility. Korean Journal of Social Welfare Studies, 50: 93-129, 2019.

Hwang Y, Yoo PS. A meta-analysis on leadership of principals, variables of teachers, variables of organization and job satisfaction of secondary school teachers. The Journal of Educational Research, 11: 215-238, 2013.
Jeon KS, Moon HG. Examination of negative sides of charismatic leadership through an empirical study in South Korea. The Journal of Training and Development, 28: 43-63, 2014.

Jeong HY, Lee K. The path model of early childhood teachers' turnover intentions with social support, depression, and burn out. Early Childhood Education Research \& Review, 18: 159-181, 2014.

Joo HJ. An exploratory inquiry on the school principals'negative leadership. The Journal of Korean Teacher Education, 31: 29-52, 2014.

Kim DY, Kim MA. A study on analysis of job satisfaction among night school teachers for people with disabilities. Journal of Special Education: Theory and Practice, 17: 293-312, 2016.

Kim JH, Yoon CS. Mediating effects of relationship quality on franchisor leadership and franchisee performance. Asian Journal of Beauty and Cosmetology, 15: 467-477, 2017.

Kim YG. A study on the job satisfaction of police officials according to job stress factors. The Police Science Journal, 10: 29-54, 2015.

Lee HJ, Beon CB, Park SJ. The structural relationships among job autonomy, affective organizational commitment, job satisfaction and knowledge sharing behavior: evidence from upscale hotels in Seoul. International Journal of Tourism Management and Sciences, 28: 145-168, 2013.

Lee HW, Jeong BG. The investigation on the needs of study of negative leadership. Journal of the Korean Human Resource Development, 15: 31-61, 2012.

Lee $\mathrm{MH}$. Convergence factor influencing job satisfaction of radiographer. Journal of Digital Convergence, 13: 357368, 2015.

Lym $\mathrm{CH}$, Lee HS. A study on the influence of abusive supervision of supervisors on organizational effectiveness. The Korean Journal of Human Resource Development Quarterly, 15: 85-115, 2013.

Lym TG, Choi WS. A the moderating effects of perceived organizational support in the effect of work value on turnover intention: focus on food-service industry newcomers less than 1 year. Management \& Information Systems Review, 35: 37-56, 2016.

Mo JH, Kim YS. The effects of capability and authenticity of 
mentors in skin care, and their similarity to mentees on mentor trust, satisfaction and turnover intent. Asian Journal of Beauty and Cosmetology, 13: 331-338, 2015.

Park JE, Park EJ. Effects of human resource management and knowledge sharing on turnover intention in the beauty service industry. Asian Journal of Beauty and Cosmetology, 15: 333-344, 2017.

Seo HJ, Kim BJ. Analysis on structural relation among employment supporting program, university educational satisfaction, job satisfaction and job match. The Journal of Education Administration, 34: 51-75, 2016.
Seong MH, Kim HW, Kim JW. A comparative study on job stress and job satisfaction between preceptors and precepts. Korean Journal of Health Promotion, 7: 131138, 2017.

Shin HJ, Lee HC, Kim JH. The effects of hotel restaurant chefs' supervision on job satisfaction with affective commitment: using the ordered probit model. International Journal of Tourism and Hospitality Research, 31: 5-17, 2017.

Yang NY, Park JH, Han DS, Lee JH. A study on factors affecting the turnover intention of occupational therapists. Korean Journal of Occupational Theraphy, 22: 39-48, 2014. 


\section{국문초록}

\section{피부미용사의 부정적 리더십 지각이 직무 만족도와 이직 의도에 미치는 영향에 대한 연구}

김문주

안산대학교 의료미용과, 경기도 안산시, 한국

목적: 본 연구의 목적은 피부미용사의 부정적 리더십 지각이 직무 만족도와 이직 의도에 미치는 영향을 살펴봄으로써 피부미용실 경영 개선의 효율적인 발전 방안을 제공하고자 함에 있다. 방법: 본 연구를 수행하기 위해 참고문헌 고찰과 설문지를 개발하였다. 본 연구의 자료는 SPSS window 19.0 프로그램(IBM, USA)을 사용하여 빈도분석, 신뢰성과 타당성 검증은 Cronbach's $\alpha$, 요인분석 및 다중회귀분석을 이용하였다. 2019년 7월 동안 전국 프랜차이즈 피부미용실 87곳, 개인 운영 피부미용실 25 곳에 근무하는 피부 미용사를 대상으로 총 560 부의 설문지를 배포하여 회수된 472 부가 분석에 사용되었다. 크론바흐 알파 값은 0.764 에서 0.824 이었 다. 부정적 리더십 요인에서 근무환경 요인 7 문항, 개인적 요인 5 문항, 직무 만족 요인에서 기회요인 8 문항, 능력 요인 4 문항, 방향 요인 4 문항으로 총 16 문항, 이직의도 요인으로 4 문항을 선정하였다. 결과: 부정적 리더십과 직무만족도 및 이직의도와의 관계에서 피부미용사에게 있어 자율적인 조직 분위기, 직무 만족, 긍정적인 동료관계가 직무만족도를 높이고 이직의도를 낮추는 것으로 나타 났다. 결론: 관리자의 부정적 리더십을 낮추고 직무만족도를 증진시키고 이직의도를 낮출 수 있는 방안 모색을 통해 피부미용실의 경영개선 및 관리자들의 부정적 리더십에 대한 관심 및 개선의지를 높일 수 있는 방안 마련이 요구된다.

핵심어: 부정적 리더십, 이직의도, 직무만족, 피부미용사, 피부미용실

\section{참고문헌}

강철희, 이종화. 사회복지사의 이직의도에 관한 연구: 직장이동과 직업 이동 분석. 사회복지연구, $50: 93-129,2019$. 김두영, 김미아. 장애인 야학 교사의 직무만족도 분석. 특수교육저널: 이론과 실천, 17: 293-312, 2016. 김용근. 경찰공무원의 직무스트레스 요인별 직무만족도에 관한 연구. 경찰학논총, $10: 29-54,2015$.

김준호, 윤천성. 프렌차이즈 본사 리더십과 가맹점 경영성과에서 프랜차이즈 관계품질의 매개효과. 아시안뷰티화장품학술

지, 15: 467-477, 2017.

모정희. 김영심. 피부미용직무에서 멘토의 역량 및 진정성, 멘티와의 유사성이 멘토신뢰와 만족, 이직의도에 미치는 영향

에 관한 연구. 아시안뷰티화장품학술지, 13: 331-338, 2015.

박정은, 박은준. 미용서비스업의 인적자원관리, 지식공유가 이직의도에 미치는 영향. 아시안뷰티화장품학술지, 15: 333$344,2017$.

배은미, 박은준. 남성 헤어디자이너의 이직의도가 직업전환에 미치는 영향에 관한 연구. 아시안뷰티화장품학술지, 13: 595-602, 2015.

서화정, 김병주. 취업준비프로그램이 대학교육만족도가 직무일치를 매개로 직무만족도에 미치는 영향. 교육행정학연구, 34: 51-75, 2016.

성미혜, 김혜원, 김자원. 프리셉터와 신규 간호사의 직무 스트레스와 직무 만족도 비교. 대한임상건강증진학회지, 7 : 131-138, 2017.

신현정, 의희찬, 김진후. 정서적 몰입에 따른 호텔 주방 부서장의 감독유형 요인과 구성원의 직무만족간 영향관계. 관광연 구저널, 31: 5-17, 2017.

양노열, 박지혁, 한대성, 이주현. 작업치료사의 이직의도에 영향을 미치는 요인. 대한작업치료학회지, 22: 39-48, 2014. 이미화. 방사선사의 직무 만족도에 영향을 미치는 융복합요인. 디지털융복합연구, 13: 357-368, 2015.

이홍재, 변찬복, 박성종. 직무자율성, 직무만족, 정서적 조직몰입과 지식공유행동의 구조적 영향관계: 서울시 특1급 호텔 
종사자를 대상으로. 관광연구, 28: 145-168, 2013.

이황원, 정범구. 부정적 리더십 연구의 필요성에 대한 고찰. 인적자원개발연구, 15: 31-61, 2012.

임창현, 이희수. 상사의 비인격적 감독 행동이 조직효과성에 미치는 영향: 상사신뢰의 매개효과와 회복탄력성의 조절 효과

를 중심으로. HRD 연구, 15: 85-115, 2013.

임태근, 최우성. 직업가치가 이직의도에 미치는 영향에 있어 조직후원인식의 조절효과: 외식업체 1 년 미만 신입종사원을 중심으로. 경영과 정보연구, $35: 37-56,2016$.

전기석, 문형구. 부정적인 측면의 카리스마적 리더십에 대한 연구. 산업교육연구, 28: 43-63, 2014.

정혜영, 이경화. 사립 유치원교사의 이직의도에 미치는 사회적 지지와 우울 및 소진의 영향. 유아교육학논집, 18: 159181, 2014.

주현준. 학교장의 부정적 리더십 연구에 관한 탐색적 고찰. 한국교원교육연구, 31: 29-52, 2014.

황연우, 유평수. 중등교사의 학교장지도성, 교사변인, 조직변인과 직무만족도에 관한 메타분석. 교육종합연구, $11: 215-$ 238, 2013. 


\section{中文摘要}

\section{负面领导意识对皮肤护理美发师的工作满意度和离职意向的影响}

金汶珠

安山大学医疗美容学科, 京畿道安山市, 韩国

目的: 这项研究的目的是提供一个有效的发展计划, 通过检查负面领导对工作满意度的影响以及皮肤美容院的转 职意向，从而改善皮肤沙龙的管理。方法: 进行文献回顾并设计问卷调查, 以评估负面领导, 工作满意度和换 工作意向。随机抽样用于选择韩国的参与者。在2019年6月管理的560份问卷中，来自472位受访者的数据被纳 入最终分析。这项研究进行了因子分析和多元回归分析, 以检查变量和Cronbach's a之间的关系, 以使用SPSS window 19.0 (IBM，USA）进行可靠性分析和有效性分析。结果：在负面领导，工作满意度和离职意向之间 的关系中, 发现自主的组织氛围, 工作满意度和积极的同事关系会增加工作满意度, 并降低皮肤美人的离职意 向。结论: 改善皮肤护理沙龙的工作环境对于创建公平的法规, 晋升和福利计划是必要的, 以减少负面领导对工 作满意度的影响。

关键词: 美容师, 打算换工作, 工作满意度, 负面领导, 护肤沙龙 